\title{
Cartaphilus
}

Revista de investigación y crítica estética

\section{LA ALEGORÍA EN BAUDELAIRE}

THE ALLEGORY IN BAUDELAIRE

\section{LUIS MERITA BLAT}

UNIVERSIDAD DE VALENCIA

Resumen: Interpreto Les fleurs du mal de Baudelaire a partir principalmente de los conceptos ofrecidos por la teoría del arte de Adorno, en un diálogo que busca la coherencia hermenéutica del poeta con las aportaciones para su comprensión de Benjamin, Jauss y Gadamer. Con el horizonte puesto en la relación entre lo artístico y el saber, distingo cuatro constelaciones de sentido en los poemas baudelairianos: la construcción alegórica de la realidad, el poeta autointerpretado como arquitecto, la poética del recuerdo y el spleen, desde cuyos marcos interpretativos esbozo materiales para una posible historia de la belleza en la modernidad.

Palabras clave: alegoría; belleza; conocimiento.

\begin{abstract}
I interpret Les fleurs du mal de Baudelaire mainly from the concepts offered by Adorno's theory of art, in a dialogue that seeks the hermeneutic coherence of the poet with the contributions for his understanding of Benjamin, Jauss and Gadamer. With the horizon set in the relationship between the artistic and the knowledge, I distinguish four constellations of meaning of Baudelairean poems: the allegorical construction of reality, the selfinterpreted poet as an architect, the poetics of memory and spleen, from whose interpretative frameworks I sketch materials for a possible history of beauty in modernity.
\end{abstract}

Key words: allegory; beauty; knowledge. 
La beauté est l'expression d'une certaine manière habituelle de chercher le bonheur Stendhal.

\section{Introducción}

La pregunta por la belleza en Adorno conduce a la interrogación acerca de las formas de representación de la mímesis, en tanto que potencia productiva artística, cuyo resultado es la expresión de los materiales en formas abiertas, cuyo significado va más allá de la definición de la teoría del arte dentro de un sistema de las ciencias que ya no estamos dispuestos a defender, en que a aquélla se le imputa la tarea de encargarse del reino de la belleza. En Adorno, la estética se convierte en filosofía, en el sentido en que aquélla interpreta el arte. La estética deviene conocimiento, no sólo de la realidad, como un testimonio crítico, reflexivo, orientativo, regulador, sino como umbral, pliegue, surco, terreno de juego de la razón del arte, extrínseca a la razón instrumental, por ser técnica sin cosificación y organización sin dominación. De la pregunta por la belleza, en la que me detendré en una lectura de algunos poemas de Baudelaire, camino hacia la interrogación sobre qué es el arte, en donde pongo a debatir las posiciones de Benjamin, Adorno, Jauss y Gadamer en torno a Baudelaire, para posteriormente preguntarme por la expresión artística en la modernidad. La pregunta que articula este escrito es la expresión en las formas artísticas de la belleza en la época de la modernidad capitalista e industrial, en donde la técnica ha invadido todos los ámbitos de la sociedad, con sus subsiguientes efectos deshumanizadores e instrumentalizadores. Veremos de qué forma autores como Walter Benjamin y Adorno han contribuido a este debate en torno a la expresión de la belleza en la modernidad debido a las transformaciones en la sociedad causadas por la expansión del capitalismo y por la industrialización. Para abordar el fenómeno de la belleza en la modernidad, el viaje teórico realizado por este estudio concierta los siguientes vértices: la noción de poeta como arquitecto, la composición alegórica de la realidad, la poética del recuerdo, el spleen y la relación entre la belleza y la verdad. Baudelaire se relaciona con la mayor parte de los movimientos artísticos de la modernidad, ya que a dicho poeta se remontan "todas las categorías como decadencia, formalismo, esteticismo", a cuya mímesis de la realidad las formas artísticas de la modernidad se refieren (Adorno, 2003: 250). La pregunta por la belleza en el capitalismo inaugura un nuevo sentido a la mímesis artística, que en la expresión narrativa crea formas, cuya relación con el conocimiento es problemática. ¿En qué sentido, de qué manera las formas de la belleza artística en la modernidad capitalista se relacionan con figuras del conocimiento? Veremos que el destino paradójico de la belleza moderna, en busca de la novedad, se convirtió en repetición; una repetición que se relaciona con la diferencia de manera sugerida, evocada, convocada a través de nexos de sentido, que en la lógica de las formas artísticas resisten en el capitalismo tardío por ser fuerzas centrípetas y 
centrífugas contrarias a la sumisión a la mercantilización.

Sorprende que Baudelaire, desde quien prevalece la doctrina de l'art pour l'art por algunos de sus epígonos formal-clasicistas, siga influenciando en obras de artistas políticamente comprometidos. "Un arte carente por completo de ideología no es posible" (Adorno, 2004: 313), sostiene Adorno, y a continuación comenta que Sartre subrayó que dicha corriente, de la que supuestamente a Baudelaire se le hace uno de sus iniciadores, contribuyó a la neutralización del arte. Sin duda, la doctrina del arte por el arte neutraliza el arte, puesto que el arte está tan políticamente comprometido como lo histórico que son los materiales con los que el artista trabaja; sin embargo, llama la atención que Baudelaire, con su apariencia formalista, logre atraer la atención de poetas posteriores comprometidos con la praxis. Baudelaire consigue, junto con Rimbaud, sugerir belleza de la fealdad debido a la mímesis de formas capaces de absorber la vida del capitalismo industrial naciente, de las ciudades, las calles, los bulevares, los centros comerciales, etcétera. La calidad estética implica progreso político. Lo artístico está íntimamente entreverado con lo político. ¿Qué elementos políticos tiene la modernidad baudelairiana? Esta cuestión nos guiará a lo largo del siguiente texto.

\section{1. ¿En qué sentido el arte es conocimiento?}

Pienso que la mímesis puede ser interpretada desde tres categorías: el tiempo, el espacio y la imaginación. La narración se articula en el tiempo, se despliega en el espacio y tiene lugar en lo espiritual de la imaginación. Las ideas de la imaginación componen el juego en el que participan todos los sentidos, en donde residen los límites impuestos por el sujeto creador en la forma artística, relacionada con el código objetivado en una obra de arte, que se despliega en el espacio constituido por el material, en un lenguaje concreto artístico, y se despliega en el tiempo en una expresión que, del lado subjetivo recoge la forma y del lado objetivo asimila el material, con una historia técnica determinada. Esto es la mímesis.

En el plano de la razón, se halla la dimensión de la significación, consistente en la expresión y en la construcción, las cuales se afianzan en un plano de inmanencia, cuyas propiedades se relacionan con su opuesto, con su alteridad, con la trascendencia, de manera intrínseca. El material refleja la promesa de felicidad, en la que la forma de la belleza se ha convertido la teoría sublime de Adorno, que sugiere la reconciliación por medio de la negación de la misma, es decir, por la exhibición de las contradicciones y antagonismos sociales, personales, de los concretos que son un mundo, por mostrar las patologías de la modernidad y los efectos de la alienación, las rupturas y los desgarros en los sectores y ámbitos sociales escindidos, y, sin embargo, unificados por la forma mercancía, absoluta figura opuesta a las formas artísticas, cuyo enfrentamiento escenifica aquélla la identidad y lo uno, y éstas la diferencia y la multiplicidad. Estamos con- 
templando la forma de representación de la mímesis desde la estructura de la razón moderna, por un lado, y desde la doble naturaleza en la que la inmanencia es trascendencia al mismo tiempo, por otro lado, por ser el material artístico un reflejo de la forma en que la humanización habría sido plenamente llevada a cabo, en una naturalización de la sociedad y en una socialización de la naturaleza, donde la obra del hombre habría sido realizada en la Tierra.

\section{La construcción moderna de la belleza.}

Baudelaire inaugura la poesía moderna en la literatura continental, siendo Whitman al otro lado del Atlántico, quien da el pistoletazo de salida a la poesía moderna anglófona. El francés revoluciona el contenido de la poesía, siendo un precursor de la modernidad artística (Adorno, 2004: 181). A diferencia de la belleza en el orden platónico expuesto en el Timeo, en el que reina la armonía de un cosmos ordenado (Platón, 2002: 182), ${ }^{1}$ Baudelaire expresó, en una actitud moderna, el rechazo a la naturaleza natural, en favor de una belleza fugitiva, del instante eterno, "que no vuelve y que deja su propia antiquité en el status del estar en el pasado" (Adorno, 1986: 148). La lógica del progreso del arte moderno describe la revuelta temática en un primer momento, para proseguir hacia variaciones en el tema, como en Rimbaud, Verlaine y Mallarmé, tanto como en la forma, hasta llegar a las innovaciones de Joyce y Beckett. Baudelaire estructura la poesía moderna, en el sentido de asignar las normas de elaboración formales de una obra poética; es decir, en su rebelión contra la tradición, instituye la serie de normas clásicas, ejemplarizantes, que en adelante configurará el anticanon (Adorno, 2004: 55), que es nuestro banal y actual International style. "Artistas de gran sensibilidad de gusto, como Stravinsky y Brecht, maltrataron al gusto por amor al gusto; la dialéctica lo ha atrapado; el gusto va más allá de sí mismo, y esto es su verdad". El arte autónomo se ve obligado a contradecirse a sí mismo para poder seguir manifestando autenticidad; es decir, el arte se apropia del no arte y deviene arte en afirmando su artisticidad. Por eso, el gusto de los artistas fue contrariado. Duchamp dijo: "me he obligado a contradecirme yo mismo para evitar adaptarme a mi propio gusto" (Elger: 2008, 82). Lo que fue buen gusto deviene tradición abolida y el mal gusto se convierte en lo rompedor, en lo rup-

\footnotetext{
${ }^{1}$ El mundo es un "ser viviente eterno", por lo que la modernidad habría consistido en un proceso de desmundanización del mundo, o, dicho con mayor exactitud, una ampliación a nivel espacial, ya que sólo la finitud espacial con que Platón describía el cosmos podía permitirle ordenar armónicamente el mundo. Sin embargo el tiempo era ya considerado según la eternidad, con lo cual la modernidad implica una caotización del mundo, ya que éste pierde su sentido, y una metaespacialización del mundo, dado que el espacio es infinito según la física moderna. Por lo tanto, si bien la infinitud espacial nos estremece, no podemos justificar científicamente la existencia de un principio ni de un fin del tiempo, ni de cualidades intrínsecas a las cosas, ni tampoco de un sentido que vertebre el mundo, la historia o la naturaleza.
} 
turista, en lo nuevo por lo que el mercado apuesta y es encumbrado a gloria del arte moderno.

\section{a. El poeta moderno como arquitecto.}

Baudelaire es un vivo ejemplo del ideal de construcción, en cuya búsqueda se coronó rey de las palabras con el agua bautismal con que comienza Les fleurs du mal, colonizando el espacio que otrora tuviera Dante para la cultura medieval o Virgilio para la cultura romana, es decir, dando la marca de lo que debía ser el despertar de un poeta. El programa creativo de Baudelaire aprovechó el movimiento de intelectualización del arte, que atraviesa toda la modernidad estética, en cuya producción se busca la aproximación del arte, paradójicamente, a la naturaleza; es decir, alejándose de la naturaleza mediante la intelectualización el arte moderno busca aproximarse a la naturaleza (Adorno, 2004: 128). El principio de construcción es la variable de la mímesis, que en este trabajo nos concierne en tanto que principio creador, por el cual los artistas modernos buscan la naturaleza en sus obras de arte. "La teoría de lo sublime de Kant anticipa en lo bello natural la espiritualización que el arte llevará a cabo" (Adorno, 2004: 129). Lo sublime intelectualizado apunta a la belleza de la forma compuesta por los elementos dispares entre sí, cuyos nexos establecen relaciones de significado específicamente artísticos, que rebasan el lenguaje del concepto.

Ante el principio de realidad, al cual Freud opone el principio de placer, se puede contraponer, más bien, el principio de construcción imaginativa de la realidad. "La construcción es la forma de las obras que no les es impuesta ya acabada, pero que tampoco asciende desde ellas, sino que brota de su reflexión mediante la razón subjetiva" (Adorno; 2004: 294). La construcción no procede del material, pero tampoco se encuentra terminada en sí misma, sino que deja ascender contenido expresivo, habiendo previamente determinado una forma desde la cual hacer hablar al mundo. La instrumentalización del ente causa el abstraccionismo en el arte, lo cual explica que Adorno diga que el momento nominalista produzca el principio de construcción. La estática de la construcción se dinamiza a través de los motivos, que desarrollan la intriga, la trama, la acción, en cuyas variaciones reside la dinámica de la construcción; lo cual apunta a la transmisión del devenir; esencia del arte: la expresión del paso del tiempo. ¿Qué dinámica puede habitar en un principio tan estático como el de la construcción? El despliegue del significado de las alegorías en Baudelaire constituye la dinámica de la construcción en sus sonetos. Sin embargo, el encantamiento del Formgefühl, al que Baudelaire no es ajeno, condujo al arte a la repetición (Adorno, 2004: 296), contra cuyo hechizo el arte debe rebelarse con formas artísticas inteligentes y críticas, que vayan más allá de la disyuntiva entre la estática y la dinámica. Adorno contempla la posibilidad de un arte del futuro con las siguientes palabras:

Algunas conexiones transversales con la tecnocracia hacen sospechar que en la 
estética el principio de construcción obedece al mundo administrado, pero puede conducir a una forma estética todavía desconocida, cuya organización racional alude a la eliminación de todas las categorías de administración junto con sus reflejos en el arte (Adorno, 2004: 297).

Caminar hacia formas estéticas aún desconocidas es una de las tareas de este estudio, en virtud de cuya idea consagro mis esfuerzos intelectuales a la interpretación de la poesía de Baudelaire. Así, el nacimiento del poeta es un disparate en términos baudelairianos (Baudelaire, 2007: 18), lo que genera la hilaridad irónica características del dadaísmo y del posterior surrealismo (Rasula; 2016: 47). Baudelaire da cuenta poéticamente de la llamada de la belleza en Le flambeau vivant, diciendo que "tout mon être obéit à ce vivant flambeau" (Baudelaire, 2007; 242). Las metáforas son las "perlas del mar", que el poeta encuentra en su camino hacia la luz, de cuyos senos procede la inmortalidad del poeta, en cuyo caminar sangra por el sufrimiento de un dios. Sufriendo por todos nosotros encuentra su palabra voz y derecho a la expresión, parodiado cómica y sublimemente por la sorpresa de la madre, ante cuya aparición no hace sino blasfemarlo y difamarlo. Interesante es aquí el oxímoron de saintes voluptés (Baudelaire, 2007: 17), en la que se conjuga una identidad heterogénea, es decir, una síntesis ideal de lo sensual y de lo beato: un ascetismo voluptuoso. Es un sacrificarse por el universal, sin perder los derechos como concreto y único.

El poeta se define a sí mismo como un Albatros, cuyas alas de gigante le impiden caminar por la tierra, pero sí volar entre nubes de imágenes cuyo lenguaje es capaz de escanciar en palabras (Baudelaire, 2007: 186). También se imagina siendo una suerte de Sísifo, cuyo trabajo - de soledades profundas- consiste en levantar el paso del tiempo, para transformarlo en formas artísticas (Baudelaire, 2007: 198). Síntesis de lo múltiple es la alegoría, cuya contradicción constituye el nexo, que impregna el himno a la belleza, al preguntarse Baudelaire si procede del cielo o del abismo; en si acaso es infernal o divina, la belleza lo gobierna todo y no responde ante nada, ni nadie; dueña de lo efímero, refulge tanto si procede del alba, cuanto si proviene del atardecer (Baudelaire, 2007: 210). El Hymne à la beauté está compuesto de las tensiones que caracterizan lo estético y lo artístico, en tanto que atravesado de lo bueno y de lo malo; no sólo en su origen, sino en su producción. Las enemistades lingüísticas contrapuestas por un magnetismo que la palabra poética otorga a la figura del oxímoron recuerdan a los versos de Quevedo describiendo el amor, por cuya lucha de contrarios fue conocido como el Heráclito español.

\footnotetext{
Es hielo abrasador, es fuego helado,

es herida que duele y no se siente,

es un soñado bien, un mal presente,

es un breve descanso muy cansado;
} 
es un descuido que nos da cuidado,

un cobarde, con un nombre de valiente,

un andar solitario entre la gente,

un amar solamente ser amado;

es una libertad encarcelada,

que dura hasta el postrero parasismo;

enfermedad que crece si es curada.

Este es el niño Amor, éste es su abismo.

¡Mirad cuál amistad tendrá con nada

El que en todo es contrario de sí mismo!

(Quevedo; 1999: 258-259)

La belleza moderna, contradictoria en sí misma, parece nacer de las entrañas del amor, que en el siglo de oro barroco español Quevedo comprende desde la contraposición inherente a su misma idea. De las cenizas del amor barroco surge la belleza moderna, en su irreconciliable contradicción entre opuestos. La unidad de lo múltiple, lo enfrentado bajo el mismo emblema, lo referido por una contradicción, lo plural reunido en una forma que respeta la concreta diferencia de cada elemento; lo alegorizado por significados contrarios, cuya heterogeneidad los reconduce a un significado más allá del lenguaje: esto caracteriza la belleza moderna, cuya disonancia expresa los antagonismos de la sociedad, convirtiéndose el espacio artístico en reflejo de las contradicciones de la sociedad. Adorno llama a la disonancia, que desde Baudelaire hasta Wagner jalona las formas artísticas, una suerte de invariancia de la modernidad estética (Adorno, 2004: 27). A lo que apunta la síntesis de la diferencia es a la sugerencia en un mundo mejor, más justo, construido según una razón sensata, inspirada por el arte, en donde lo singular se respeta en su idiosincrasia.

La unicidad comparece en el canon de las prohibiciones, de lo que en términos éticos no debemos realizar, desde el criterio estético es favorable y deseable que sea realizado por esa autonomía, cuya trascendencia alcanza la verdad de la historia de la naturaleza; es decir, las normas del gusto por lo prohibido. El juicio estético moderno es, en sí mismo, una valoración, que sin Baudelaire no se puede imaginar. Adorno dice que "en el canon de las prohibiciones se sedimentan las idiosincrasias de los artistas, pero éstas son obligatorias objetivamente; ahí, lo particular es literalmente lo general" (Adorno, 2004: 55). Se tra- 
ta de una ascensión desde lo particular y concreto hasta lo general, porque en lo particular se sella un rasgo universal, que es generalizado precisamente por su particularidad.

Tu me déchires, ma brune,

Avec un rire moqueur,

Et puis tu mets sur mon coeur

Ton oeil doux comme la lune.

Sous tes souliers de satin,

Sous tes charmants pieds de soie,

Moi, je met ma grand joie,

Mon génie et mon destin. (Baudelaire, 2007: 269)

Esta concreción se convierte en lo general a través del gusto. El gusto moderno se habitúa a la ascensión beatífica desde lo sensorial hacia la salvación en la redención de una belleza realizada por la imagen, por la calidez de las imágenes que desprenden los versos, ordenados aún según rigidez formal propia de la época del siglo XIX, pues Baudelaire no rompe la claridad y la distinción de los sonetos. No son anglófonos, es decir, isabelinos, puesto que no terminan con dos versos, sino que son sonetos continentales, ya que tienen la estructura de 4-4-33. El antinaturalismo de Baudelaire en busca de la multiplicación de individualidades a través de la experiencia estética pretende hacer sensible lo abstracto mediante la alegoría (Jauss, 1995: 83). Más allá de la nostalgia por la naturaleza, deposita sus esperanzas el impulso poético en la alianza entre la industria y el arte, en lo que Adorno viene a considerar como mímesis de lo cosificado. Entre la humanización de la industrialización y la respuesta en busca de un equivalente a la industrialización en la figura de la mímesis de lo reificado, se encuentra la poética de Baudelaire.

El arte abstracto está llamado a conseguir la pureza en el arte, en lo que al construir un mundo nuevo, el mundo de lo sensible y lo concreto; para que lo único y lo múltiple tengan los mismos derechos que lo universal y lo abstracto. Baudelaire es un precursor de la búsqueda de la construcción en la revolución del arte moderno (Sedlmayr; 2008: 116). La técnica es fundamental en las cualidades de la composición formal de la obra de arte. Esta tendencia camina hacia el cubismo y el abstraccionismo en la pintura. La figura retórica del oxímoron es algo más que un juego entre dos concretos diferentes que se amalgaman entre sí dando lugar a una unidad problemática y cambiante en sí misma; es, en realidad, la figura lógica del antagonismo que en la literatura y en especial, en la poesía, mimetiza los conflictos sociales. La identidad heterogénea constituye el sintagma 
desde el cual se pueden interpretar los campos de fuerza generados por las constelaciones de conceptos, que son elementos psico-sociales conflictivamente relacionados entre sí en las realidades que habitamos.

Ahí donde veamos mímesis de lo negativo, que es el dolor injustificable producido por factores sociales, veremos mímesis del antagonismo $y$, en este sentido, veremos una identidad heterogénea, es decir, creación de una síntesis de opuestos en los cuales se da a ver una serie de sentido causante de dolor, y por la cual el pensar aspira a actuar a través del concepto. El texto está plagado de diferentes figuras retóricas remitentes al oxímoron, que son las imágenes alegóricas de Benjamin, síntesis de contrarios, red de tensiones, carga de opuestos, choque de trenes, fisura en el abismo del ser, apertura de lo imprevisible en la contraposición de lo diferente, que remiten a los antagonismos sociales y, en concreto, en el específico sentido en que se manifiesta la contraposición en la poesía La vie antérieure, donde se columbra el saber poético que reposa sobre las voluptés calmes; lo cual de nuevo nos da la pista sobre el rumbo a tomar en nuestras interpretaciones. Se trata de un platonismo voluptuoso, de una sabiduría heraclítea del cuerpo, de un materialismo de la luz. Lo que aquí es atacado de la obra de Platón es su ascetismo y su condena a los sentidos y a lo sensible, que en realidad es un gesto altivo hacia la experiencia en alianza con el supuesto poder de la dialéctica, lo cual da a la filosofía una pose de arrogancia a ojos del poeta. La palabra poética no está sustraída de placer, sino que en su luz, experimenta el cuerpo placer a través de la apropiación material de las imágenes.

El poeta aspira a encontrarse en el azar de la rima hiriendo con versos antaño soñados. El poeta, en el sentido en que es creador, ennoblece a las cosas con sus obras artísticas, y eso le confiere, además de admiración por sus congéneres, la capacidad de expresar bellamente lo feo. En el ennoblecimiento del mundo por la forma del arte reside la potencia crítica de la mímesis. El impulso poético, la pulsión de poesía, se encuentra en la simbolización de la realidad a partir de la alegoría. "Tout pour moi devient allégorie" (Baudelaire, 2007: 309); alegorización ontológica, que conduce a imaginar lo percibido desde la metáfora o la metonimia, en un juego de asociaciones, en donde el significado vuela de una imagen a una palabra, producida por la melancolía, ánimo tradicionalmente creativo. Paradójicamente, el acto creativo, que transforma, performa y abre realidades nuevas, surge del recuerdo nostálgico hacia el pasado. La creación se nutre de todo el espectro temporal. Por eso, la belleza es un recuerdo del futuro; un crear, aquí y ahora, desde el pasado para el futuro.

La abundancia de las contraposiciones semánticas prolifera en los poemas de Baudelaire. Así, por ejemplo, el desierto y el bosque caracterizan las caricias en la poesía "Chanson d'après midi", de la mujer castaña, cuyos ojos son dulces como la luna (Baudelaire, 2007: 109-111). Los ojos es el sentido privilegiado para retratar lo bello, y la visión el órgano que prevalece en la relación del poeta con la belleza. Con mímesis de lo mortal, Adorno asimila lo que Benjamin con anterioridad pensó como poesía de la vivencia del shock, en que se ha convertido la 
existencia de los individuos en las ciudades industrializadas (Benjamin, 2014: 162). Con la "imagen estridente" Baudelaire según Benjamin produce alegorías en la dirección de contagiar los impactos producidos por las descompuestas vivencias en las cuales se ha convertido la agrietada experiencia de la modernidad.

\section{b. La construcción alegórica de la realidad. (Baudelaire, 2007: 357)}

Bella y en una rica envoltura, la alegoría la representa Baudelaire con tanta belleza, que sería capaz de lograr el perdón por cualquier infamia (Baudelaire, 2007: 357). La naturaleza está escrita en lenguaje alegórico; en su poesía vemos desfilar fuerzas, intensidades, grados, centros de gravedad en torno a fuentes de significado interrrelacionados. La alegorización de la realidad es un fenómeno en el que la expresión sintoniza con las cualidades de las cosas. La belleza de la naturaleza adquiere su forma artística en el lenguaje alegórico. "Baudelaire realiza la transmutación de los valores estéticos de la naturaleza, con lo que se abandona el asidero de la estética platónica, que todavía llevaba implícito, el concepto de símbolo de la literatura romántica" (Jauss, 1986: 146). En realidad, el arte es antiplatónico por insumisión al ideal y reivindicación de lo concreto y específico, puesto que abandona las representaciones ideales. La pintura fue antiguamente la búsqueda pictórica mediante avances metódicos y técnicos de la representación más fidedigna a la realidad. De ahí que el Renacimiento y el descubrimiento de la perspectiva sean vistos a todas luces como un progreso en el ámbito artístico. Sin embargo, no deja de perseguir el ideal de la verdad en tanto que esencia ideal, en tanto que representación inteligible del mundo; con lo cual rechaza el mundo sensible, la representación fenoménica de la realidad. La elección de la alegoría en vez del símbolo abre a un proceso de intelectualización en el arte que destituye los fundamentos de la representación en favor de la imagen (Holzwarth, Taschen, 2016: 227). ${ }^{2}$ La primacía de la forma avanza hacia la disolución de las formas. Lo apolíneo, lo ordenado, lo matutino, el lirismo armónico da lugar a lo dionisiaco, lo caótico, la embriaguez, al lirismo disonante. El suprematismo es el arte nietzscheano por antonomasia. Pues procede no tanto según la lógica de la representación, sino de la presentación pura de las cosas con independencia de la imitación a una realidad que sometiera a la expresión; ésta, la expresión, es libre sin las ataduras de la representación objetiva. Es la libertad del devenir. Es la libertad de lo trágico, en el sentido en que Nietzsche otorga a dicho término en El nacimiento de la tragedia (Nietzsche, 2005: 99).

¿Qué es la vivencia según la hermenéutica si no recuerdo, esto es, ejercicio de descosificación alcanzada por la operación de la dialéctica en su apropia-

\footnotetext{
2 "La expresión de un concepto del mundo liberado del objeto es el logro más sobresaliente del arte de este siglo", pues, "para los artistas del siglo xx, el cuadro con perspectiva central y punto de fuga fijo representa es imagen obsoleta del mundo que pretendían sustituir con un nuevo vocabulario de formas".
} 
ción crítica de las realidades irracionales? Gadamer y Adorno a través de espejos concéntricos. Lo vivido es lo recordado, que viene a ser descosificado por la acción de la memoria, y así la vida se hace menos alienante. "Lo que llamamos vivencia en sentido enfático se refiere pues a algo inolvidable e irremplazable, fundamentalmente inagotable para la determinación comprensiva de su significado" (Gadamer, 2012: 104). Estamos ante el contenido conceptual rebasado por el arte, que abre las puertas de la vida en la experiencia estética; momento anticartesiano de la estética por su querer alcanzar lo artístico mediante conceptos. El carácter de aventura del sentido, de aquello rebasado por la concepción mecánico-afectiva del mundo por la categoría de vida, coincide con el contenido de la mímesis, que sobrepasa en tanto que lenguaje del arte al lenguaje del concepto.

La incertidumbre caracteriza la aventura, (Gadamer, 2012: 106) como la botella lanzada al mar de la desesperanza con que escriben Dialéctica de la llustración Adorno y Horkheimer. El sentido de la superación atribuido por Gadamer señala lo que de enriquecimiento y madurez conlleva la aventura, cuando se supera una prueba o un examen que dicha vivencia ha impuesto. Son aventuras las que experimenta Odiseo en el primer excurso de Dialéctica de la llustración escrito por Adorno, de las que se apropia, se extingue, se diferencia, y vuelve a sí mismo cambiado, superada la prueba, más robusto, más capaz, con mayor fortaleza. "En la vivencia del arte se actualiza una plenitud de significado que no tiene que ver tan sólo con este o aquel contenido u objeto particular, sino que más bien representa el conjunto del sentido de la vida" (Gadamer, 2012: 107). La verdad comparece en la experiencia a través del arte, desde donde el hombre contempla la vida en su multiplicidad de prácticas sociales. Hasta qué punto esa plenitud de significado representada por la obra de arte puede lograr una vivencia del conjunto del sentido de la vida, en donde el sentido se despliega a través del arte en una biografía concreta, donde lo singular alcanza lo universal mediante el arte a través de la experiencia estética, es problemático. ¿No es la crisis del sentido lo que caracteriza la razón de ser del arte moderno? (Adorno, 2004: 205) 3 ¿Tuvo alguna vez, acaso, sentido la existencia, la historia, el mundo? "Las obras de Beckett son absurdas no por la ausencia de sentido (entonces serían irrelevantes), sino en tanto que discusión sobre el sentido. Desenrrollan la historia del sentido" (Adorno, 2004: 207). El sinsentido en que nos vemos instalados en la modernidad tardía nos conduce a plantearnos todas estas cuestiones. Parece que la deconstrucción de la forma, la desarticulación de lo que fue la lógica de la representación fuera lo verdaderamente moderno. El rasgo modernizador en el arte no es sólo la intelectualización a causa de la primacía de la forma, sino la dotación de sentido mediante la desarticulación de los nexos tradicionales de

\footnotetext{
${ }^{3}$ En donde Adorno sostiene que las obras de arte adquieren su carta de naturaleza moderna, su plenitud, en la desarticulación de los nexos de sentido que en la tradición fueron considerados formas plenas de significado.
} 
sentido. Los modernos recogemos el sentido del sinsentido, de aquello que una vez fue creído con sentido.

A esto apunta la rehabilitación de la alegoría, que como el símbolo, designa un sentido que no consiste en su mera manifestación, en su aspecto o en su sonido, sino en un significado que está puesto más allá de sí mismo (Gadamer, 2012: 110). Alegoría y símbolo no tienen en su origen nada que ver el uno con el otro. Originariamente, la alegoría forma parte de la esfera del hablar, del logos, y es una figura consistente en dejar de decir aquello que verdaderamente se quiere significar por un sintagma, que a pesar de todo permita comprender aquello que se quiere referir. Todo recae en la relación entre lo que se dice y lo que se quiere decir, cuya distancia, sin embargo, cuya proximidad, mejor dicho, permite comprender lo significado por medio de lo dicho. Lo dicho se relaciona alegóricamente con lo significado. En cambio, el símbolo no está restringido a la dimensión del hablar, sino que es su propio ser sensible el que tiene significado. Se diferencia el símbolo de los logotipos de las empresas, en que aquél presupone un nexo metafísico de lo visible con lo invisible. La alegoría, por su parte, no sólo remite a un sentido de la interpretación, sino también a representaciones de conceptos abstractos a través de imágenes en el arte. "Símbolo es la coincidencia de lo sensible y lo insensible, la alegoría es una referencia significativa de lo sensible a lo insensible" (Gadamer, 2012: 112). Desde el punto de vista de la decisión de Baudelaire en favor de la alegoría, se trata una elección posidealista, propia de una crítica a la poesía desde el empirismo materialista. La alegoría es el símbolo moderno; es decir, son símbolos sin sentido metafísico.

La alegorización del arte en la modernidad responde a una separación de lo dicho con el significado, de manera que el sentido se eleva, por la sugerencia, por la evocación, del significado. La alegorización del arte responde a su evolución antiplatónica a contrapelo de las injusticias y del sufrimiento social ocasionado por el capitalismo en las sociedades que habitamos, en donde el símbolo, viejo heredero de la idea platónica, unidad de la esencia de la palabra con la cosa, se convierte en la alegoría, en la que la relación del significante deja de aspirar a conectar elementos metafísicos con el significado. La alegoría procede de una desacralización del símbolo. Desde este punto de vista, la pretensión de Adorno de construir una casa a la metafísica en el territorio de la estética (Adorno, 2004; 456) resulta tanto más difícil cuanto que la alegoría, frente al símbolo, pierde formalmente la conexión entre las partes en el todo que es la obra de arte, que permitiría una relación de la obra con la experiencia metafísica. La belleza moderna se relaciona con el recuerdo de la experiencia metafísica, con su sugerencia y su evocación; no necesariamente con la vivencia directamente vivida. Esto es una liberación y una pérdida: lo primero, porque libera al arte de las ataduras a las que Platón lo subyugó para fines militaristas y disciplinarios y, por lo tanto, la alegoría significa una ampliación de la libertad en la creación de formas artísticas; lo segundo, porque las formas alegóricas pierden su intrínseca relación, que el símbolo sí tenía, con elementos metafísicos, debido, quizás, a la 
posibilidad crecientemente democratizada por las innovaciones vanguardistas de producirlas con cierta destreza en el manejo del lenguaje.

La alegoría constituye un elemento indispensable de la aisthesis en la formación de cualquier persona culta perteneciente a esta nuestra modernidad (Jauss, 1995; 145). La alegoría es el paradigma de la recepción en la delimitación de los criterios de comprensión del significado artístico del poema. Según Jauss, la alegoría es un medio empleado por Baudelaire para lograr la despersonalización de la expresión poética, huyendo del subjetivismo y del simbolismo del romanticismo. El modernismo de la elección de Baudelaire por la alegoría radica en una búsqueda para dar testimonio de su experiencia con el hachís dentro del trabajo permanente en torno a la contemplación de la belleza, en el marco de una teoría de la creación poética basada en el sueño voluntario, en la ensoñación. Lejos del romanticismo, la imaginación es potenciada a través de la alegorización de la realidad. El modernismo consiste en la prevalencia del objeto frente a las pasiones del alma del sujeto, en una preponderancia por narrar lo acontecido, por transmitir realidad y generar una vivencia dentro de la experiencia. La expresión es real, en la medida en que se inscribe en la realidad a través de la descripción y de la observación. La poética de Baudelaire es uno de los fundamentos de la Teoría estética de Adorno en lo que se refiere a la expresión. El poeta describe la experiencia del ensueño poético como una "multiplicación de la individualidad" (Jauss, 1995: 146), en lo que recuerda a la multiplicación de líneas de fuga que acontecen con la experiencia de las alegorías de Kafka interpretadas por Deleuze, deviniendo máquinas metafóricas de nuevos escenarios a nivel social y ontológico (Deleuze, 1975: 146); interpretación que ilumina experiencias tan dignas de admiración por su incomparable vigor metafórico como, por ejemplo, la lectura de Ante la ley (Kafka; 2002; 111).

En el transcurso del arte moderno comparecen una serie de debates, en los cuales los artistas esgrimen un modo de interpretar la categoría de signo estético en función de las nociones de alegoría, en donde la relación con la realidad, con la idea es siempre problemática y a veces rebasada, yendo el signo estético más allá de la idea, generando, por lo tanto, un simulacro, una forma artística cuyo conocimiento sobrepasa el concepto general e instituye una norma nueva con derechos en ámbitos sociales siempre a discutir en democracia. Me da la impresión de que a la estética le pesa aún la reminiscencia de la idea platónica, de la cual deben participar la copia y el simulacro. Por lo tanto, a medida en que la obra de arte deviene no arte en arte a través de la apropiación de lo que no es arte, es decir, se convierte en copia, éste se muestra cada vez más parecido al no arte, al simulacro, que al arte propiamente dicho, a la esencia de lo que una vez fue arte. ¿Qué es el canon de las prohibiciones? La soberanía estética declara la excepción ética en su comportarse artístico. ${ }^{4}$ Entre la delicadeza y el refinamiento se encuentra el delgado hilo de lo escrito para captar que el buen gusto reside

\footnotetext{
${ }^{4}$ El dadaísmo, el surrealismo y la performance son ejemplos vivos de esta experimentación.
} 
en la prohibición. Los gestos subversivos, disparatados, transgresivos, escandalosos, de los dadaístas y de los surrealistas, eran claros ejemplos de ellos. La prohibición en el arte tiene sentido porque se encuadra dentro de una práctica artística y está en diálogo con una tradición, que permite leer la acción artística, en un disponerse ante el pasado, lo heredado, y reubicarlo, cartografiarlo a la luz de una nueva taxonomía. La alegoría es la expresión del arrobo ante el desierto del sentido. Así, el flâneur y la alegoría son estrategias poéticas contra el desgarramiento de la sociedad y del lenguaje, cuyo hedonismo asceta se ubica en un estar dentro y fuera de la ciudad, desde cuya distancia puede sazonar su distinción estética y criticar el capitalismo (Baudelaire, 1995: 22).

Goethe muestra conocimiento de la producción artística, al señalar que no tiene nada que ver que el artista busque lo particular en función de lo universal, que el ver lo universal en lo particular (Benjamin, 2006: 377). En esto último reside la posibilidad de crear alegorías, como la que visiona la belleza en tres mujeres: en ángel de la guarda, en musa y en madona (Baudelaire, 2007: 242); lo cual recuerda al cuadro del pintor expresionista noruego Munch (Bischoff, 2006: 46). De ello trata la poesía de Baudelaire, ya que desde la crisis de la modernidad, la estética busca en su transgresión de la tradición la transformación de los itinerarios artísticos hacia nuevos caminos y horizontes de creación, en los cuales se sintetice una diferencia capaz de absorber las contradicciones y generar acciones políticas, con vistas a la racionalización sin alienación, ni cosificación. La soberanía estética vendría a ser la percepción de lo universal mediante lo particular y de lo particular en lo universal, pero siempre con la primacía de lo concreto, de la fuente o proceso de donde surge la luz hacia lo general. En toda escritura hay rasgos alegóricos, ya que los signos son ruinas de imágenes desgastadas por su uso corriente. En la alegoría aún pervive la magia del signo, ya que aquélla constituye nexos de sentido entre palabras para apresar el tiempo. El tiempo se deposita en las relaciones establecidas entre las palabras, que constituyen las alegorías. Quizás, a través de la comprensión del tiempo, las alegorías, que son símbolos modernos, se yerguen en tanto que conocimiento de la sociedad. La comprensión alegórica es "como un relámpago que ilumina de pronto la oscuridad de la noche", un instante de fecunda brevedad (Benjamin, 2006: 380). La diferencia entre la captación totalitaria del símbolo y la comprensión por momentos de la alegoría apunta al abismo del movimiento dialéctico, al que se asoma quien penetra por la intuición en una figura alegórica, según comenta Benjamin (Benjamin, 2006: 377). Lo alegórico se despliega siempre de nuevo de modo sorprendente, a diferencia del símbolo, que se mantiene idéntico a sí mismo (Benjamin, 2006: 402).

Baudelaire menciona en algunas ocasiones el término "symbolique" (Baudelaire, 2007: 57) para referirse a la fría majestuosidad resplandeciente de la mujer estéril, a quien Lorca dedicará un drama teatral con Yerma; un autor que pasó por el surrealismo con dos obras de importancia: Poeta en Nueva York y El público (Lorca, 2016). El símbolo juega un papel de extrañamiento, de distancia; 
es una figura que auratiza la cosa simbolizada. Pero es sobre todo con el sintagma forêts de symboles cuando la sacralización de la naturaleza, es decir, de los sentidos, de los perfumes, los colores y de los sonidos es conducida a su extremo (Baudelaire, 2007: 188). La palabra que deviene símbolo va más allá de lo que dice. El símbolo es, al mismo tiempo, imagen y concepto, lo cual se ve literalmente en el término alemán Sinnbild (Gadamer, 2012: 116). Si el símbolo oculta, evocando y sugiriendo significado, la alegoría visibiliza. La alegoría presenta un doble carácter enigmático, referente a la historia en general y a la biografía concreta de cada individuo, resaltando los pliegues en los que se dibujan los signos de interrogación en torno a agujeros que ni el sentido de la historia, ni de la existencia puede llenar de significación (Benjamin, 2006: 380). En los agujeros negros resaltados por la comprensión fisurada de la alegoría comparece la historia de los sufrimientos del mundo, una visión que impone una misión; la de rescatar el sentido de lo desaparecido, del llanto por las miserias y males del mundo. En este sobrepasar al concepto logra la alegoría desplazarse en lo miserablemente cualitativo, en las intensidades de los sufrimientos cotidianos; logra, en una palabra, la alegoría, deslizarse a través de los pliegues del dolor de las realidades que habitamos. Ejemplo de ello es el poema "Le masque", dedicado a una estatua alegórica, que llora por haber vivido, por vivir, y por tener que vivir (Baudelaire, 2007: 209). La alegoría es una máscara viva del tiempo fugazmente eterno producido por la belleza artística.

"La belleza de la naturaleza consiste en que la naturaleza parece decir más de lo que es" (Adorno, 2004: 110); aproximación a una posible definición de la belleza de Adorno, en donde la desarticulación de los nexos de sentido constituye su sentido; lo cual puede ser un modelo desde el cual pensar la alegoría y la utopía de una sociedad reconciliada. La belleza del arte es el sentido del arte. ¿De qué manera podemos leer a Adorno cuando plantea que la belleza es algo formal, de acuerdo con un principio de orden e impregnado de cualidades transitorias mínimas? (Adorno, 2004: 75-76). El ideal de la composición y de la estructura basadas en la técnica, el cual está en relación con la dirección histórica, cuyo rumbo el arte ha tomado en la modernidad en su búsqueda de la pureza en la significación, se inspira en la geometría y en lo cuantificable. Se trata de la dinámica significativa de la sucesión. El formalismo de lo bello en Adorno se debe interpretar a la luz de la intelectualización del arte en su Teoría estética ocurrida en todas las artes (Adorno, 2004: 128) y, especialmente, en el género musical del jazz, criticado sin embargo por este filósofo por no contener rasgos de música auténtica, puesto que la autonomía del arte según la creencia de Adorno es propiedad exclusiva de la cultura occidental (Adorno, 2008). Es indudable que el mestizaje resultado de la música negra del siglo XX contiene rasgos de autenticidad. Sea como fuere, la belleza de la alegoría no reside en el contenido propiamente dicho, sino en la relación entre lo significado y lo enunciado, entre el signo y la imagen, en cuyo nexo se encuentra la relación que otorga belleza a los elementos en juego. 
La belleza es siempre, inevitablemente, de una composición doble, aunque la impresión que produzca sea una; porque la dificultad para discernir los elementos variables de lo bello en la unidad de la impresión no invalida en absoluto la necesidad de la variedad en su composición. Lo bello está hecho de un elemento eterno e invariable, cuya cantidad es excesivamente difícil de determinar, y de un elemento relativo y circunstancial, que será, si se quiere, alternativamente o al mismo tiempo, la época, la moda, la moral, la pasión (Baudelaire, 1995: 78). La eternidad de la belleza se combina con la fugacidad de la experiencia de lo bello. Se describe así la relación, esencial a la belleza, entre lo infinito y lo temporal y cómo la eternidad se inscribe en lo pasajero. Si el alma es la imagen del cuerpo, la huella de la infinitud de la obra de arte se desvela en la lógica de la apariencia sensorialmente transitoria, con lo cual la paradoja de la multiplicidad en una unidad estética imposible de culminar se desenvuelve en la experiencia de la belleza, la cual es considerada por Adorno como el tour de force de la apariencia (Adorno, 2004: 145).

La belleza es la sugerencia, lo evocado, hacia lo que tienden los elementos en su relación para con el todo que es la unidad estética que acontece en un proceso productivo y receptivo. El formalismo de lo bello de Adorno se distancia de la materialidad y del efecto, subrayando el momento estructural, geométrico, matemático, orgánico de la relación sobre la que se sostiene la belleza. El contenido de la belleza en Adorno es la forma de la obra de arte auténtica. La forma de la obra de arte bella expresa el sufrimiento producido por la sociedad injusta, en el sentido en que la forma expresa disonancia, tensión, contraposición, contraste entre elementos dispares. La forma está viva, porque transmite y sumerge en la experiencia de dos o más fuerzas en liza, cuya dialéctica es la vitalidad de la forma. "La pérdida de tensión es la objeción más grave contra algún arte contemporáneo; la indiferencia en la relación de las partes y el todo es otra manera de decirlo" (Adorno, 2004: 77). Que la diferencia se encuentre en el centro de la forma, como su esencia más propia, asigna un lugar a la pluralidad en relación con la belleza. A través de la forma se encuentra la multiplicidad de la diferencia en la belleza, en su irreconciliable relación entre contrarios, la belleza emerge de la estructura sugerida y evocada por la obra de arte.

Constato la tensión al pensar el arte entre la crítica basada en el juicio estético y la interpretación fundada en la experiencia estética. No sólo entre el idealismo y el empirismo se debate el pensamiento estético, que vendría a equivaler a la dicotomía entre el juicio o la experiencia, sino entre el Antiguo Testamento y Homero. Jauss contrapone la narración según el tiempo del presente dominante de la llíada con el tiempo mesiánico garantizado sólo por la fe, que establece una relación oculta de lo pasado con lo futuro (Jauss, 1986: 124-125). El vitalismo que rezuma el decantarse por la interpretación, en vez de por la crítica tiene lugar en la afirmación del placer de los sentidos, fuente inagotable de reflexión desde el arte. El placer y la verdad se encuentran en la experiencia estética interpretada a la luz de un sibarita placer intelectual considerable como 
hedonismo asceta, o ascetismo artistizado. Se trata de una afirmación de la vida por medio de la negación de la sociedad en la creación estética, cuya obra de arte contiene las disonancias causantes de placer (Adorno, 2004: 61). A la base de esta actitud hacia el mundo se halla la categoría de símbolo en un amplio sentido, la cual fundamenta la búsqueda de la belleza a través de las transformaciones de la modernidad en materia artística. La simbolización de la realidad es la afirmación desde el arte de la vida, del tiempo de los sentidos y de la reflexión por el placer en la experiencia estética generada, el cual conduce a una serie de verdades que conciernen al sentido de la existencia del hombre.

\section{c. Poética del recuerdo.}

Benjamin vio en la teoría de la mémoire volontaire el método de lograr la verdad de la belleza en Baudelaire (Benjamin, 2014). En el recuerdo converge la naturaleza y la historia entrelazadas. Dice Kundera que "la lutte de l'homme contre le pouvoir est la lutte de la mémoire contre l'oubli" (Kundera, 1978). En el olvido reside el poder de la dominación, que gana terreno a la memoria, verdadera facultad de la resistencia contra la pérdida de experiencia y contra la ideología injusta del capitalismo tecnificado. Contra el tiempo injurioso se levanta en actitud prometeica el poeta, al cual acusa de asesino de la vida y del arte; al olvido, al cual advierte de que nunca matará en su memoria las mujeres que fueron su placer y su gloria (Baudelaire, 2007: 237). Se trata de una poesía del recuerdo, así termina "le vin du souvenir" en el poema La chevelure; o, como lo reconoce el mismo Baudelaire en su poema llamado Une charogne:

Les formes s'effaçaient et n'étaient plus qu'un rêve,

Une ébauche lente à venir,

Sur la toile oubliée, et que l'artiste achève

Seulement par le souvenir. (Baudelaire, 2007: 222)

Se trata de formas que el poeta sueña a través de la urdimbre del tiempo mediante el recuerdo. Jauss convierte a Baudelaire un precursor de la literatura del recuerdo, siendo Proust el artista que lleva a realización esta poética junto con una teoría de la praxis creativa (Jauss, 1986: 145). Baudelaire se acerca a los experimentos formales del cubismo con poesías como "L'harmonie du soir" (Baudelaire, 2007: 99), en la que construye la triste belleza del corazón, que "odia la amplia nada y el negro", cuya tristeza se refleja en el cielo y en el sol, por el recuerdo de una flor que se evapora como la tarde. La vertiginosa melancolía fricciona y vibra como un violín afligido. "Entre le rêve et la vie, le poète cherche sa voie, et comme un nouuvel équilibre qui serait natural et normal - la nuit et le jour, l'invisible et le visible ayant pareillement droit à sa sollicitude et formant deux mondes complémentaires, deux modes accordés de la réalité essentielle" 
(Raymon, 1952: 16). Esta descripción biográfica surcada por dos itinerarios entrelazados, la vida y el sueño, el caos y el orden, el éxtasis y la belleza, lo dionisiaco y lo apolíneo, constituye la realidad existencial de Baudelaire.

El saber poético es el recuerdo de la preexistencia del alma en el mar. La luz es marina, como atestigua la imagen les soleils marins. No es el dios olímpico al que está haciendo referencia Baudelaire, pero tampoco es al dios de la guerra y al de los infiernos, aunque a veces, por el tono paródico y de burla, pueda resonar Ares. La belleza habita en el mar. Poseidón es el dios al que canta Baudelaire. Los pórticos del mar no refieren a la esperanza, sino a la belleza. El frontispicio del reino del mar debería decir: "dentro de estas fronteras, no cabe la fealdad" (Dante, 1965). El mar es el territorio de la belleza. El saber de la mímesis se alimenta de la verdad destilada por la altura y por las dimensiones, por la profundidad y los ecos del espacio abierto o vacío de las insondables cimas del dolor. Son los "secretos dolorosos" de la ilustración los que son aireados por los versos del poeta, cirujano de la cultura a través de las operaciones en la piel de los signos -que son los poemas para los afectos del alma-; hermenéutica que aquí se pone en marcha hacia un proceso de autonomización del discurso. El poeta confiesa que lo que le hace vivir, la razón de su existencia, es el cuidado por profundizar en el lenguaje del dolor y del sufrimiento, que es el arte poético; siendo, por tanto, su canto, un lamento confesional o una confesión lamentándose. El anhelo constituye al gesto del poeta, cuya palabra está constituida por el deseo de intimidad requerido para el género confesional, y el lamento por la incomprensión ante la injusticia experimentada en carne propia. En la medida en que confiese sus vicios y faltas, en que pregunte por las causas de su sufrimiento, poetizará las huellas del dolor que sobre el sí mismo la sociedad ha dejado huella, y preguntará a Dios por su dolor. El lamento y la confesión resuenan en la invocación de Baudelaire con el inicio de las Flores del mal.

El hombre está ligado al mar por la libertad, ya que el aliento libre persigue la mar como los colores a la luz. El mar es la libertad. El mar posibilita la libertad del hombre y es límite a la libertad del hombre. El mar es el espejo del hombre, en donde podemos ver el eco del mito de Narciso, quien se veía reflejado en las aguas de un río. El sujeto y el objeto, hombre y mar, son tan desconocidos el uno para sí mismo, como el uno para el otro. Su saber sobre sí mismo y sobre el otro es escaso y van en busca del conocimiento de la alteridad y de sí mismos. Pero la interioridad del alma del hombre, la insondable profundidad del mar son dimensiones inhabitadas por el sol marino, luz del saber poético. De la misma forma en que el sujeto, en tanto que alma, y el objeto, en tanto que cosa en sí, en la teoría del conocimiento kantiana permanecen vedados para el saber posible. La experiencia poética se hace eco de este límite.

Homme, nul n'a sondé le fond de tes abîmes;

O mer, nul ne connaît tes richesses intimes. (Baudelaire, 2007: 27) 
Si lo trágico se constituye por lo sabido y lo ignorado, el mar se inscribe en el horizonte trágico del hombre, por ser nudo de la ignorancia en el medio de la existencia humana. Empleado en el poema Moesta et errabunda, el mar constituye una alegoría del consuelo debido al cansancio producido por el trabajo (Baudelaire, 2007: 274). En La musique conmueve Baudelaire al decir que "La musique souvent me prend comme une mer!" (Baudelaire, 2007: 282). Música, consuelo y libertad caracterizan alegóricamente al mar en Baudelaire. En esta búsqueda del camino en la república de la belleza, que es la navegación a través del mar, éste dejará de ser la metáfora de la amada, para convertirse en el amigo/enemigo en términos políticos, constituyéndose en la alteridad por excelencia del hombre, la naturaleza y su ser objetividad, contra la cual el ser humano se enfrenta y se dispone para vencer a sus adversarios en la lucha por la vida. Es interesante ver en qué sentido Baudelaire concibe el enfrentamiento entre el hombre y el mar. Si éstos son guerreros eternos, luchadores que acuden a la llamada del destino, necesidad implacable, en cuyo escenario el tiempo se expresa en cada uno de los combatientes, por no ser el hombre más que la forma y el mar la materia en que se expresa la temporalidad, la historia de la naturaleza.

\section{d. El spleen.}

Benjamin dice que el hombre moderno tiene la vivencia del mundo sin experiencia, a cuya pérdida de dicho elemento vital de la existencia entra en conocimiento con el sentimiento, que se cierne sobre sus estados de ánimo por la llegada de los domingos (Baudelaire, 2007: 194). El vacío resultante es la caída, el spleen: la angustia y el terror por una vida imposible de llenar, vacía a pesar de todo. En el momento de la caída, la nada lo inunda todo y la angustia arrebata el aire al flâneur, al paseante solitario entre la multitud, que se adentra en las ciudades modernas armado de su soledad. "J'ai plus de souvenirs que si j'avais mille ans", dice Baudelaire en uno de sus spleen, donde la expresión logra estremecer cuando reconoce que "je suis un cimetière abhorré de la lune" (Baudelaire, 2007: 289). El cénit expresivo llega cuando el poeta francés explora el infierno que Adorno citará en Minima moralia (Adorno, 2006: 167): "Avalanche, veux-tu m'emporter dans ta chute" (Adorno, 2006: 293).

Adorno se refiere en sus "Paralipómenos" a Nietzsche, según el cual el spleen de Baudelaire apunta a la posibilidad de un mundo artístico y antimetafísico (Adorno, 2006: 167). La modernidad baudelaireana se refleja en un mundo gobernado por la voluntad de poder, más allá del bien y del mal, en donde la muerte de dios pone en duda la conveniencia, utilidad y función social de la poesía, pero ésta sobrevive adaptándose a la novedad imparable del ritmo trepidante del capitalismo. En los tiempos nihilistas a los que se refiere el spleen, el arte muta por su desacralización y desauratización, adopta figuras no artísticas, asimila lo que no es arte, y obtiene de la mercancía algunas de sus características, para poder sobrevivir en tanto que mercancía, ya que en el capitalismo Les fleurs du mal tuvieron que adaptarse a la difusión de discursos en el mercado capitalis- 
ta en tanto que valor de cambio. Con un mundo antimetafísico pero artístico apunta Baudelaire con su spleen, que viene a ser el mundo soñado de los poetas y filósofos, cuyo fin es recobrar el paraíso perdido; un jardín de verdadera belleza formada por palabras e imágenes o alegorías, en donde sujeto y objeto se reconcilien, y donde todo tenga sentido; una beatitud artística. La desjerarquización de la realidad y la trascendencia intramundana de la percepción estética potenciada por la ebriedad caracteriza la ontología baudelairiana. Más allá del platonismo del reino de lo bello, lo verdadero y lo bueno, Baudelaire formula la profundidad del espacio, que se convierte en alegoría de la profundidad del tiempo: el sueño de una modernidad reconciliada por el arte de la poesía (Jauss, 1995: ,151).

La influencia de Baudelaire en Nietzsche se percibe en la construcción de la belleza de aquél desde la queja, extraña y secreta, comunicada por un ángel: "Que rien ici-bas, n'est certain" (Baudelaire, 2007: 95), en donde la incertidumbre que, según Nietzsche es una de las figuras del mal, se convierte en el saber del devenir, en la luz del paso del tiempo, en el río de Heráclito en cuyas aguas batallan el ser y el no ser. Sabiduría que Nietzsche atribuye a la tragedia en sus orígenes, la cual mana de la palabra de Sileno, jefe de los sátiros, que decía que lo mejor habría sido no ser (Nietzsche, 2005). Pero tenemos que vivir y, al igual que el arte, perseverar en el ser (Adorno, 2004: 61). Según Adorno, lo que se acerca al satanismo en Baudelaire, es el resultado de la identificación de su poesía con la negatividad de la sociedad, ya que todo lo artístico auténtico se entrega a lo acusado en su acusación crítica en la que se enarbola la obra de arte. Adorno valora en Baudelaire que "ni combate la cosificación ni la copia; protesta contra ella en la experiencia de sus arquetipos, y el medio de esta experiencia es la forma poética" (Adorno, 2004: 36). Con el spleen entra lo feo en la modernidad artística, de manera que el arte no sólo se dedica al ideal, sino que amplía sus dominios por entre los intersticios de lo esquivo y huidizo; momento de lo feo que acompaña la intelectualización del arte hacia el formalismo abstracto (Adorno, 2004: 73). Ante la Entzauberung del mundo, la poesía de Baudelaire reacciona con un encantamiento alegórico de las cosas, con una remitificación de los conceptos, que deberían situar al lector ante un politeísmo poético. Es el anhelo el estado de ánimo que gobierna el éxtasis poético configurador de la realidad descrita por la poesía de Baudelaire.

Sorprende que una de las tendencias del arte moderno en su despliegue de su recién descubierta autonomía sea su liquidación en tanto que tendencia de desarrollo, como si la desauratización fuese un proceso intrínseco a la intelectualización de la belleza artística, en cuya forma se desacraliza los elementos trascendentes, al tiempo en que se produce el aura de lo nuevo (Adorno, 2004: 111). "En Baudelaire se produce y niega a un tiempo la trascendencia de la aparición artística" (Adorno, 2004: 111). A esta se refiere Adorno con la trascendencia quebrada, esto es: la forma cuya finalidad inmanente es fisurada. Si el aura es una aparición, por lejana que pueda estar (Benjamin, 2006), el arte moderno se desauratiza en su manifestación por el despliegue de su autonomía, cuya pro- 
ducción, al entregarse a lo cosificado y alienante, es conducida, asombrosamente, a una desartización, en la que elementos intraestéticos pierden valor artístico por, paradójicamente, su valor artístico. Se trata de la consecuencia por mimetizar mediante la forma el contenido múltiple y disperso procedente de las sociedades complejas contemporáneas. Si la mímesis está constituida por la unidad y la expresión se configura siempre por lo múltiple, es, a fin de cuentas, la mímesis de lo múltiple en lo que consiste la expresión; una racionalización sin cosificación (Adorno, 2004: 101). La producción artística consiste en una configuración mimético-constructiva de lo cosificado sin cosificación (Adorno, 2004: 157).

La caída es la subversión; el ideal es la belleza del mar: las flores del mal es el oxímoron remitente al spleen et l'idéal para referirse al mal realizado por la libertad, puesto que se trata de una subversión para la libertad. La flor, alegoría de la liberación de una sustancia viva en un abrirse hacia el espacio en una expansión de su dinámica hacia afuera, constituye el símbolo de la liberación estética. La territorialización de la flor con la avispa está en función de la delicadeza

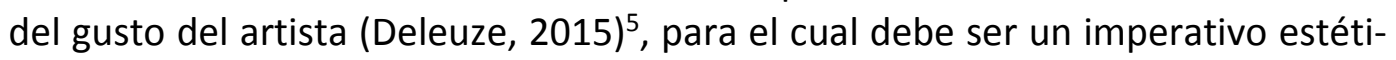
co la excepción ética en favor de una autonomía estética siempre por lograr y por justificar en su legitimidad ética, puesto que entra en colisión con las normas del derecho y de la convención establecida. En la configuración de la autonomía estética, la desacralización de la belleza colisiona con las leyes establecidas en la forma de lo convencional, establecido, acostumbrado y legislado bajo los criterios de la normalidad y de lo prescrito por los códigos legislativos. Dos luces sobre el mundo: la belleza de Poseidón y la justicia de Zeus; la legitimidad del mar y la legalidad de la tierra se enfrentan en la configuración por la autonomía del arte. La belleza es guiada por la vida, que desafía a la ley igual para todos, en nombre de la unicidad y la diferencia de lo vivo; pues lo artístico reclama los derechos de lo viviente. En este sentido, el arte es promesa de la naturaleza: voz de lo oprimido por la marcha de la civilización en la historia; siendo Auschwitz el lugar para designar la muerte del ejemplar. Las obras de arte son inconmensurables. Son perspectivas de las realidades que habitamos. La igualdad reside en la diferencia que las hace sublimes.

Resuena en La mort des pauvres (Baudelaire, 2007:373) el monólogo del ser o no ser de Hamlet en lo concerniente al premio y recompensa significados por la muerte, en tanto que consuelo. Lo triste de esta poesía es la renuncia implícita a la que se refiere Baudelaire exigida a los pobres, que carecen de otro sustento para soportar los males, las preocupaciones y los dolores de la existencia más allá de la muerte. En el más allá, en el orden extramundano, es en el que

5 "La orquídea se desterritorializa al formar una imagen, un calco de avispa; pero la avispa se reterritorializa en esa imagen. No obstante, también la avispa se desterritorializa en esa imagen, deviene una pieza del aparato de reproducción de la orquídea; pero reterritorializa a la orquídea al transportar el polen. La avispa y la orquídea hacen rizoma, en tanto que heterogéneos". 
puede repararse el sufrimiento acaecido durante la vida, para quienes durante la existencia no puede haber sosiego. Si la muerte es un consuelo, la vida no tiene sentido. El poema muestra el grado de injusticia, para quienes dejar de existir puede ser un alivio. Para los desposeídos, la muerte es la única esperanza. Se asemeja al monólogo de Hamlet en el sentido en que éste pregunta por qué debemos cargar con los males, antes bien de que volar hacia otros que ignoramos, ante cuyo fenómeno no queda sino afirmar que la conciencia nos hace cobardes. Sólo en un mundo comprendido a la luz de una existencia ultramundana puede interpretarse este poema. Más allá de la muerte de Dios, que fue poetizada por Hölderlin en su poesía Pan y vino (Hölderlin, 2009: 173), lo que interesa aquí es la denuncia y la crítica a una sociedad, cuyo trabajo explotado es posible gracias a la ideología de la existencia ultramundana. En este sentido, Marx afirmó que la religión es el opio del pueblo (Marx, 1968: 7). Si dejar de existir es el fin de la vida, ésta no puede encontrar asidero, sentido, ni valer la pena, ya que es devaluada en su infinita riqueza. Fiel a la consigna homérica según la cual Odiseo prefiere ser siervo en la tierra a reinar en el territorio de los muertos (Homero, 1982), Baudelaire afirma la vida y protesta contra el sistema económico, cuya explotación conduce al suplicio, que desfigura la muerte en un consuelo, al tiznar la vida de sufrimiento.

Quizás uno de los mejores poemas de Baudelaire, L'horloge (Baudelaire, 2007: 300) relata el paso del tiempo a través de la materialidad de los aparatos encargados de la medición del curso temporal. En primer lugar, el reloj, "dieu sinistre, effrayant, impassible", donde destaca la imagen del "plaisir vaporeux fuira vers I'horizon"; el segundero susurra: "Souviens-toi! - Rapide", en donde el uso de la mayúscula no es por casualidad, sino que éstas designan a lo largo de Les fleurs du mal una coreografía de significados, que se desplaza generando campos magnéticos de sentidos, evocadores, llenos de sugerencias dentro del propio poema y en relación con las poesías configurando un conjunto heterogéneo de, digámoslo así, funciones semánticas, que arrojan luz sobre vivencias, imágenes, recuerdos, palabras, evocadoras de una verdad inmanente, que va más allá de la representación habitual del término. "C'est la loi." El tiempo es la ley. Ingobernable, tiránico sobre los hombres, el tiempo se apodera de todo lo existente y domina todas las realidades. El tiempo es el hábito de la vida, de la realidad, del mundo. Hasta el mismo intelecto divino está cargado de tiempo. La naturaleza y la historia son el resultado de procesos temporales. Baudelaire toma partido por el azar frente a la necesidad. El azar dentro de la necesidad, sin embargo, del "il est trop tard!", con que se despide el poema; necesario porque la vida siempre mira hacia adelante, pues el vivir es un proyectarse, con lo que resultaría truncado el aliento vital ante la muerte, la esposa del tiempo, implacable en su gobierno. El arte es la representación mimética del paso del tiempo. Baudelaire logra una buena poesía, al recordarnos nuestra finitud: la vanidad de toda existencia.

Me parecen acertadas las palabras de Horkheimer al respecto de la poe- 
sía francesa del siglo XIX: "Los simbolistas franceses disponían de una noción particular para expresar su amor a las cosas que habían perdido su significación objetiva: la palabra spleen" (Horkheimer; 2002). Spleen denota lo que ha perdido el sentido. "La arbitrariedad consciente, desafiante, en la elección de los objetos, su 'absurdo', su 'perversidad', descubre con gesto silencioso, por así decirlo, la irracionalidad de la lógica utilitarista a la que golpea en pleno rostro a fin de demostrar su inadecuación a la experiencia humana. $Y$, al traer ese gesto a la conciencia, gracias a ese choque, el hecho de que aquella lógica olvida al sujeto, expresa, al mismo tiempo, el dolor del sujeto por su incapacidad de lograr un orden objetivo" (Horkheimer, 2002). La contradicción en la que entra el arte es similar al antagonismo que desestructura la sociedad moderna, en el sentido en que la asimilación de la novedad es la directriz de la reconstrucción del orden del mundo, que ha entrado en crisis en la modernidad, buscando, para ello, el poeta moderno, encontrarse a sí mismo en lo arcaico y fugaz, pero eterno (Adorno, 2006: 244).

El hombre moderno creativo hace de la incertidumbre que gobierna a la novedad una flor, convirtiendo en estímulo el horror y la desesperación del ritmo trepidante del crecimiento industrial capitalista. El afán por la novedad no es falsa conciencia, ni tampoco conciencia correcta, sino el testimonio de la pérdida de la experiencia a causa de los males por la industrialización capitalista. Adorno critica la búsqueda denodada por lo nuevo, puesto que el descubrimiento de lo nuevo es lo satánico en la figura del "eterno retorno como maldición" (Adorno, 2006; 245). La ontología baudelairiana constituye la idea de la modernidad, cuya esperanza se basa en la autodestrucción permanente de las fuerzas para su retroalimentación en el choque con la realidad cosificada. La novedad, espejismo de la belleza, quizás, no sea más que la repetición de lo arcaico, cuya negación se busca desesperada para el consuelo en el mundo de la cultura, que abarca distintos sectores sociales y puede remontarse a distintas tradiciones; pues, "todo puede enajenarse de sí mismo como nuevo y convertirse en goce" (Adorno, 2006, 247). Convertida en sensación, la novedad termina por desvelarse como una regresión en el esteticismo de l'art pour l'art, que recuerda a la compulsión a la repetición freudiana. En consecuencia, la verdadera distinción artística se la juega en la elaboración de una correcta mímesis, que desconfíe de las llamadas a la novedad, hoy por doquier divulgadas desde los portavoces del International Style, y busque qué y quién son cielo en este infierno.

\section{La belleza y la verdad.}

La belleza es la verdad del mar, mientras que la verdad es la belleza de la tierra; mar y tierra, luz de la belleza, que es la verdad, y luz de la verdad, que es la belleza, las cuales se encuentran en las alegorías de Baudelaire, constelaciones de sentido, en cuyos escenarios se dibujan las contradicciones de nuestra modernidad. La luz de la belleza es alegorizada por Baudelaire a partir de una poesía, cuyo nombre apunta a esta visión que el poeta quiere transmitirnos: "Le 
flambeau vivant"; en la que el escritor se conduce hacia la route du Beau, en donde tout mon être obéit à ce vivant flambeau (Baudelaire, 2007: 83); resplandor, llama, fulgor producido por la belleza. La belleza es descrita solapadamente por Baudelaire en el siguiente verso del poema "Le crépuscule du matin": "L'air est plein du frisson des choses qui s'enfuient" (Baudelaire, 2007: 338). La fugacidad del "silencio de eternidad" (Baudelaire, 2007: 337) en torno a cuya belleza se reúne la experiencia de la alegoría como forma de conocimiento, en tanto que sugerencia, evocación, aspiración, recuerdo, sueño, en suma, descosificación, reparación, elevación, reflexión y crítica. Baudelaire ofrece gracias a estas imágenes una vivencia de la contemplación sub especie aeternitatis a través de la historia, que las alegorías son capaces de equilibrar en su frágil relación de acción recíproca.

La relación entre la belleza y la verdad plantea la pregunta por el estatuto de conocimiento de las formas artísticas de la modernidad, el cual conduce a la paradoja de la negatividad del arte en virtud de la irracionalidad de la realidad, cuya negación es realista en su sentido crítico. Esta es la posición de Adorno. La correspondencia de la obra de arte con respecto a la realidad, cuya relación le otorga verdad al contenido artístico, es la negación de la sociedad. La verdad de Baudelaire reside en la belleza de lo negativo, de lo crítico, de lo resistente, de lo subversivo y disruptor respecto del sistema. La belleza de la modernidad recoge su verdad de la negación de la realidad.

Baudelaire se enfrenta a la relación entre la verdad y la belleza en el poema L'amour du mensonge, donde la posición del poeta es irónica y ambigua, puesto que, en primer lugar, visiblemente, rehúsa determinar la naturaleza en tanto que conocimiento del arte, al no ser decisivo para admirar la belleza detenerse en si es máscara o esencia, idea o expresión adecuada. Pero, en segundo lugar, Baudelaire es un poeta, pretendiente al trono de la belleza, al parnaso de la poesía moderna. En este sentido se pregunta el francés: "Mais ne suffit-il pas que tu sois l'apparence?" (Baudelaire; 2007: 331), en donde la promesa no es proyectada hacia el futuro, para que tenga sentido, sino que la belleza, y la promesa de felicidad que lleva en su seno, es la luz de cualquier presente. El aura de la apariencia es la solicitud de detención del instante, eterno, sin embargo, abierto a convertirse en parajes de sentido repartidos en presentes sobrecogidos por experiencias estéticas. Baudelaire retrata la mímesis con las palabras "amor que sabe", que se recoge en la madurez de unas antorchas, que en el atardecer resplandecen como una aurora. Se trata de uno de los poemas más próximos de Baudelaire, en los que el sentido del humor y la distancia, tal vez altanera, con que desprecia querer saber sobre si el arte es conocimiento, como si no le bastara la categoría de la apariencia, no puede dejar de mostrar el desasosiego con que se devana una profusión de preguntas lanzadas al lector con desesperado apremio.

En una de las cuestiones, Baudelaire juega con la alegoría del "recuerdo del futuro": "Es-tu le fruit d'automne aux saveurs souveraines?" (Baudelaire, 
2007: 330). En este tercer sentido, no deja de ser irónico que la belleza sea expresada poéticamente por quien desprecia inspeccionar acerca de la naturaleza c/ognoscitiva del arte, ya que Les fleurs du mal puede ser interpretada como una inversión de lo que fuera bello en una idealización de los contrarios a los valores estéticos tradicionales. No es la permanencia, sino la fugacidad; no es la asceta beatitud, sino la beatitud de azufre; no es el alma en su diálogo con Dios, sino que es el poeta quien mantiene una conversación con Satán; no es el bien, es lo malvado lo que atrae la mirada curiosa del poeta. La Umwertung de los valores de Nietzsche podría rastrearse genealógicamente hasta, al menos: Les fleurs $d u$ mal, cuya obra destituye los fundamentos del canon antiguo. Baudelaire, por esta creación de valores estéticos nuevos, actúa frente al nihilismo vaciador de la subjetividad anteponiendo nuevas realidades a partir de experiencias nuevas. El poema que parece haber influenciado más a Nietzsche en la concepción del superhombre es Le voyage, en que Baudelaire describe a los verdaderos viajeros, caminantes de la vida: quienes viajan por el puro deseo de viajar "coeurs légers, semblables aux ballons,/ De leur fatalité jamais ils ne s'écartent,/ Et, sans savoir pourquoi, disent toujours: Allons!". En la afirmación de la vida, que capacita para seguir adelante ante cualquier circunstancia por amor al viaje, metáfora de la vida, reside la fortaleza de los auténticos viajeros, cuya potencia constituye uno de los rasgos principales del superhombre, el cual valora por encima de todo la vida.

\section{Conclusión}

Adorno añade, en referencia a Stendahl sobre su frase de la promesse de bonheur en relación a la belleza, que "el arte da las gracias a la existencia al acentuar lo que en ella alude a la utopía" (Adorno, 2004: 412). La alegoría aspira a la utopía, ya que se trata de una figura que, por la paradoja en su relación establecida con la realidad, la sugiere, la enuncia, la musicaliza, la honra. En una dialéctica entre opuestos en la que constan, de un lado, lo antiguo del afán de novedad característico de los inicios de la modernidad, y de otro lado, lo nuevo de la conservación de lo antiguo por la predilección actual hacia las vanguardias heroicas, me despido con un poema de Baudelaire llamado, La beauté, el cual quizás aspire a una repetición arcaica de lo irónicamente nuevo, lo cual tal vez produzca la diferencia deseada por subversiva en los saberes y en las realidades que habitamos:

Je suis belle, ô mortels! Comme un rêve de Pierre,

Et mon sein, où chacun s'est meurtri tour à tour,

Est fait pour inspirer au poéte un amour

Éternel et muet ainsi que la matière. 
Je trône dans l'azur comme un sphinx incompris;

J'unis un coeur de neige à la blancheur des cygnes;

Je hais le mouvement qui déplace les lignes,

Et jamais je ne pleur et jamais je ne ris.

Les poètes, devant mes grandes attitudes,

Que j'ai l'air d'emprunter aux plus fiers monuments,

Consumeron leur jours en d'austères études;

Car j'ai, pour fasciner ces dóciles amants,

De purs miroirs qui font toutes choses plus belles:

Mes yeux, mes larges yeux aux clartés éternelles! (Baudelaire, 2007: 205)

\section{BIBLIOGRAFÍA:}

ADORNO, Theodor (2008). Escritos musicales. IV. Madrid: Akal. Traducción de Alfredo Brotons Muñoz.

(2006). Minima moralia. Madrid: Akal. Traducción de Joaquín Chamorro Mielke.

------- (2003). Intento de comprender Fin de partida. Notas sobre literatura. Madrid: Akal. Traducción de Alfredo Brotons Muñoz.

-------- (2004). Teoría estética. Madrid: Akal. Traducción de Jorge Navarro Pérez.

ALIGHIERI, Dante (1965). Divina comedia. Barcelona: Editorial Mateu.

BAUDELAIRE Charles (1995). El pintor de la vida moderna. Murcia, Colección de Arquitectura.

------- (2007). Les fleurs du mal. Chênes: La bibliothèque française.

BENJAMIN, Walter (2014). Baudelaire. Madrid: Abada.

------ (2006). Obras. Madrid: Abada.

BISCHOFF, Ulrich (2006). Munch. Köln: Taschen.

DELEUZE, Gilles (1975). Kafka. Pour une littérature mineure. Paris: Minuit.

DELEUZE, Gilles (2015). Mil mesetas. Valencia: Pre-textos. Traducción de José Vázquez Pérez y Umbelina Larraceleta.

ELGER, D. y GROSENICK, U. (Eds.) (2008). Dadaísmo. Bonn: Taschen. Traducción 
de Pablo Álvarez Ellacuría.

GADAMER, Hans (2012). Verdad y método. Salamanca: Sígueme. Traducción de Ana Agud Aparicio y Rafael de Agapito.

HÖLDERLIN, Friedrich (2009). Antología poética. Madrid: Cátedra.

HOMERO (1982). Odisea. Madrid: Gredos.

HORKHEIMER, M. (2012). Crítica de la razón instrumental. Madrid: Trotta.

HOLZWARTH, H. W., TASCHEN, L., (ed.) (2016). Arte moderno. Colonia: Taschen.

JAUSS, H. (1986). Experiencia estética y hermenéutica literaria. Ensayos sobre el campo de la experiencia estética. Madrid: Taurus. Traducción de Jaime Siles y Ela Ma Fernández-Palacios.

------- (1995). Las transformaciones de lo moderno. Estudios sobre las etapas de la modernidad estética. Madrid: Visor. Traducción de Ricardo Sánchez Ortiz de Urbina.

KAFKA, Franz (2002). La metamorfosis y otros relatos. Madrid: Diario EL PAÍS.

KUNDERA, Milan (1978). Livre du rire et de l'oubli. Paris: Folio. Traducción de François Kérel.

LORCA, Federico (2016). Teatro completo. Barcelona: Galaxia Gutenberg.

MARX, Karl (1968). Introducción para la crítica de la Filosofía del derecho de Hegel. Buenos Aires: F. C. E.

NIETZSCHE, Friedrich (2005). El nacimiento de la tragedia. Madrid: Alianza. Traducción de Andrés Sánchez Pascual.

PLATÓN, (2002). Diálogos. VI. Filebo, Timeo, Critias. Madrid: Gredos.

QUEVEDO, Francisco (1999). Antología poética, Madrid: Biblioteca Nueva.

RASULA, Jed (2016). Dadá. El cambio radical del siglo XX. Madrid: Anagrama. Traducción de Daniel Najmías.

RAYMOND, Marcel (1952). De Baudelaire au surréalisme. Paris: Librairie José Corti.

SEDLMAYR, Hans (2008). La revolución del arte moderno. Barcelona: Acantilado 